\title{
ARTIGO
}

\section{LOCAL ECOLOGICAL KNOWLEDGE (LEK) ON THE MANGROVE CRAB Ucides cordatus (LINNAEUS, 1763): FISHERY PROFILE OF MANGROVE AREAS IN ITANHAÉM (SOUTHEAST BRAZIL)}

CONHECIMENTO ECOLÓGICO LOCAL (CEL) SOBRE O CARANGUEJO DE MANGUE UCIDES CORDA TUS (LINNAEUS, 1763): PERFIL DA PESCARIA EM ÁREAS DE MANGUEZAL EM ITANHAÉM (SUDESTE DO BRASIL)

Fernanda Vargas Barbi de Souza ${ }^{* 1,2}$, Marcelo Antonio Amaro Pinheiro ${ }^{1,2}$

\begin{abstract}
:
The mangrove crab (Ucides cordatus) is a relevant fishery resource in Brazil, whose capture, transportation, and processing are regulated by specific laws. Information obtained from traditional crabbing communities are of significant importance, although they remain unacknowledged by the population of the Itanhaém River Estuary (São Paulo, Southeast Brazil). The present study shows the ethnozoological aspects related to the capture of $U$. cordatus, mapping the activity and providing subsidies for better fishery management. Crab catchers were recruited using the Snowball sampling technique and were submitted to a semi-structured questionnaire. The data were assessed quali-quantitatively through the Collective Subject Discourse (CSD) method and underwent statistical analysis when possible. The population of crab catchers was exceedingly small, comprising a remnant of "caiçara" fishermen, 78\% of whom did not have a valid license, thus rendering their professional activity illegal. Most of the crab catchers (56\%) use the tangle-netting technique, which is prohibited by law, including during the fishing season (60\%). Around $77.4 \%$ of the traditional knowledge of these fishermen was confirmed in the literature, evidencing the great deal of wisdom that is passed on by more experienced crab catchers. Important gaps could be filled regarding the knowledge on this species, including the regularization of this artisanal form of fishery, requiring a review and new alternatives to be properly managed.
\end{abstract}

\footnotetext{
São Paulo State University (UNESP), Biosciences Institute (IB), Campus of the São Paulo State Coast (CLP), Crustacean Biology Research Group (CRUSTA), Laboratory of Biology for Crustacean Conservation, Praça Infante Dom Henrique, s/nº, Parque Bitaru, 11330-900, São Vicente, SP, Brazil.

${ }^{2}$ Graduate Program in Coastal Environment Biodiversity (PPGBAC), UNESP IB/CLP. *vargas.barbi@unesp.br
} 
16 LOCAL ECOLOGICAL KNOWLEDGE (LEK) ON THE MANGROVE CRAB Ucides cordatus (LINNAEUS, 1763): FISHERY PROFILE OF MANGROVE AREAS IN ITANHAÉM (SOUTHEAST BRAZIL)

Keywords: environmental assessment; "uçá"- crab; Ethnobiology; participatory mapping; fishery resource.

\section{Resumo:}

O caranguejo de mangue (Ucides cordatus) é um importante recurso pesqueiro no Brasil, cuja captura, transporte e processamento são regulamentados por legislações específicas. As informações obtidas nas comunidades tradicionais de caranguejeiros são de grande importância, embora não haja estudos conhecidos com a população de coletores de caranguejo do Estuário do Rio Itanhaém (São Paulo, Sudeste do Brasil). O presente estudo mostra os aspectos etnozoológicos relacionados à captura de $U$. cordatus, mapeando a atividade e fornecendo subsídios para um melhor manejo pesqueiro. Os coletores de caranguejos foram amostrados utilizando a técnica "bola de neve" e submetidos a um questionário semiestruturado. Os dados foram avaliados quali-quantitativamente por meio do método do Discurso do Sujeito Coletivo (DSC) e submetidos à análise estatística, quando possível. A população de coletores de caranguejo era excessivamente pequena, constituindo um remanescente de pescadores "caiçara", dos quais 78\% não possuíam licença válida, o que tornava ilegal a sua atividade profissional. A maioria dos coletores de caranguejo (56\%) utilizava a técnica da redinha, que é proibida por lei, inclusive durante a temporada de defeso pesqueiro (60\%). Cerca de $77,4 \%$ dos conhecimentos tradicionais desses pescadores foram confirmados pela literatura, evidenciando a grande sabedoria que é repassada pelos coletores de caranguejo mais experientes. Lacunas importantes podem ser preenchidas sobre o conhecimento dessa espécie, incluindo a regularização dessa atividade pesqueira artesanal, reavaliação da legislação e novas alternativas para o manejo adequado.

Palavras-chave: avaliação ambiental; caranguejo-uçá; Etnobiologia; mapeamento participativo; recurso pesqueiro.

\section{Introduction}

Ucides cordatus (Linnaeus, 1763) is a brachyuran crustacean popularly known as the mangrove crab that lives in close association with mangrove tree vegetation (NASCIMENTO, 1993; MELO, 1996; PINHEIRO and FISCARELLI, 2001; SHIH et al., 2016), playing a crucial role in the flow of matter and energy along the food chain ( $\mathrm{KOCH}$ and WOLFF, 2002). Being herbivorous, this animal feeds on senescent leaves and propagules, which are preferably collected at night, during low tide, storing them in chambers in its gallery (CHRISTOFOLETTI et al., 2013). According to these authors, due to their digging habits, these crabs promote the processing of mangrove litter and bioturbation of sediments, providing them oxygenation and altering their physicalchemical properties during this process. Their close association with the mangrove dynamics can affect the entire trophic chain and ecosystem balance, which are disadvantaged by this animal's population decline, inadequate management, and the lack of compliance with the legislation in force (PINHEIRO et al., 2015).

Reports on the mangrove crab's economic relevance date back to the 14th century, standing out as a key fishing resource due to the high protein content (72\%) and 

(LINNAEUS, 1763): FISHERY PROFILE OF MANGROVE AREAS IN ITANHAÉM (SOUTHEAST BRAZIL)

reduced levels of fat (1.8\%) of its meat, being appreciated as a delicacy and commercialized by crab catchers, also known as 'crabbers' (MELO, 1996; PINHEIRO and FISCARELLI, 2001; PINHEIRO et al., 2015). Costa-Neto and Gordiano-Lima (2000) also highlighted its medicinal use by traditional communities (in Bahia and Alagoas, Northeast Brazil), which use the fat from their hepatopancreas for menstrual regulation and their shell powder as an antiasthmatic.

Crab catching is a typical extractive practice in Brazilian mangroves that is developed by traditional coastal communities (called "caiçaras"), which is accountable for the second most profitable artisanal fishing activity of this resource (HATTORI and PINHEIRO, 2003; DIELE et al., 2005; FAO, 2020). The capture of these animals in Brazil is carried out using specific techniques, some of which are permitted by law (IBAMA, 2003), including the "braceamento" method (manual capture), "chuncho", and "gancho" (hooking), and others which use is prohibited, such as the "redinha" technique (tanglenetting), "vanga" (shoveling), "tapado", and "carbureto" (PINHEIRO and FISCARELLI, 2001). According to these authors and the SMA Resolution No. 64/2015, in the "braceamento" technique, the catcher introduces their hand/arm into the gallery until they feel the animal, which is captured by its dorsal region, avoiding its claws. While inserting their hand into the gallery, the catcher grabs some mud from the inner wall of the gallery and places it on the animal. When the crab is brought to the surface involved in this sediment, it becomes static and more docile to handle. By using this technique, the catcher avoids causing injury to the animal and can easily perceive if it is molting (ecdysis) or if it's too small for commercialization, in which case the crab can be released, complying with the environmental laws in force. The tangle-netting technique, on the other hand, consists of a trap made of raffia bag fibers and mangrove tree branches (one or two), which are placed at the opening of the galleries. Upon leaving the den, the animal gets entangled, remaining trapped until it is captured by the crab catcher.

The intensification of the mangrove crab extraction process, combined with the absence of information or non-observance of events in its biological cycle (e.g., Reproductive Period and Growth Period), as well as the introduction of illegal and impacting crabbing techniques (e.g., tangle-netting, "carbureto", shoveling or "vanga", and "tapado" in the southern and southeastern states of Brazil), have led to a reduction in their minimum capture size and, consequently, their natural stocks (IBAMA, 1994). Since the application of IBAMA Ordinance No. 52/2003 (IBAMA, 2003), several elements focused on the conservation, management, and sustainable use of the species have been developed regarding their capture, maintenance in captivity, transportation, processing, storage, and commercialization. With SMA Resolution No. 64/2015 (SMA-SP, 2015), in turn, licensing quotas were established for the harvesters of this crab on the Central Coast of the State of São Paulo, which covers the municipality of Itanhaém.

The mangrove crab species was once threatened by overexploitation (RODRIGUES et al. 2000; PINHEIRO and RODRIGUES 2011) and is considered as 'Near Threatened' (NT) in Brazil, according to IUCN standards, as stated by Pinheiro et al. (2016), and the Ministry of the Environment (MMA, 2014). It also appears on the List of Species of Wild Fauna in the State of São Paulo, requiring higher specificity in fishery management and planning for its conservation (SÃO PAULO, 2014; HARKOT et al., 2017). 
18 LOCAL ECOLOGICAL KNOWLEDGE (LEK) ON THE MANGROVE CRAB Ucides cordatus (LINNAEUS, 1763): FISHERY PROFILE OF MANGROVE AREAS IN ITANHAÉM (SOUTHEAST BRAZIL)

The fishing profile of the municipality of Itanhaém (SP) is typically artisanal, being carried out by independent producers supported by family labor, with modest capital, simplified productive means, and non-mechanized capture methods, based on empirical knowledge (MPA/MMA, 2011). The local ecological knowledge of artisanal fishing communities allows us to learn, contextualize, and propose strategies for resource management and the regularization and valorization of this professional activity (FISCARELLI and PINHEIRO, 2001; BARBOZA et al., 2008; MACHADO et al., 2018; SOUZA and PINHEIRO, 2020). According to these authors, it also serves as a database for the adequacy and reformulation of public policies related to the fishery resource and its habitat. Although there are several similar studies on this topic in other communities throughout Brazil, the only published ethnobiological data on crab catchers from Itanhaém were compiled by Souza and Pinheiro (2020), providing information on the socioeconomic profile and environmental perceptions regarding the conservation status of the mangrove ecosystem and the mangrove crab resource. Past data concerning the municipality of Itanhaém only mention that fishermen without vessels from the Praia dos Pescadores beach lived off the capture and commercialization of this crab (NAMORA et al., 2009). According to these authors, the number of fishermen there has varied considerably since 1920, comprising a community of approximately 30 families.

The monitoring of fishing activity in the municipality of Itanhaém (SP) is conducted through the inspection of 16 points of discharge (runoff) of production, comprehending, according to the Fisheries' Structural Census of the 2009-2010 biennium, a total of 72 active Productive Units in a universe of 136 fishermen involved in these activities. Regarding the capture and commercialization of the mangrove crab, this municipality relies on only two production units (2017: 1.8 ton.; and 2018: 1 ton.), resulting in revenues of US\$ 6.8 thousand and US\$ 3.7 thousand, respectively (PMAP-SP, 2018), considering conversion values of US\$1.00 = R\$ 3.31 for 2017; and US\$ $1.00=\mathrm{R} \$ 3.87$ for 2018.

The present study can be justified by the following: 1) the ecological and economic importance of the mangrove ecosystem and the mangrove crab; 2) the lack of published data on the ethnobiology of the mangrove crab catchers in the study area; 3) the need to raise awareness among crab catchers in favor of the conservation of local biodiversity; and 4) to gather information about Man, his interactions with the environment, and his fishing resources, including cultural aspects, which are useful for environmental and species management (CORTÊS et al., 2014).

Based on the previously mentioned information, the aim of this study was to compile ethnozoological data related to mangrove crab (Ucides cordatus) catching regarding seasonal closures and techniques for capturing/mapping the capture areas, thus better characterizing this fishery activity and enabling its adequate management and administration.

\section{Material and Methods}


19 LOCAL ECOLOGICAL KNOWLEDGE (LEK) ON THE MANGROVE CRAB Ucides cordatus (LINNAEUS, 1763): FISHERY PROFILE OF MANGROVE AREAS IN ITANHAÉM (SOUTHEAST BRAZIL)

The present study was structured in two stages: 1) compilation of ethnocarcinological information on mangrove crab fishing (closed fishing seasons and capture techniques) by way of interviews; and 2) identification and participatory mapping of mangrove crab capture areas in the mangrove forests of the Itanhaém River, in the State of São Paulo, Brazil.

\subsection{Study area}

The Itanhaém Estuarine System (Figure 1) constitutes the main part of the Itanhaém River Basin $\left(23^{\circ} 50^{\prime}-24^{\circ} 15^{\prime} \mathrm{S} ; 46^{\circ} 35^{\prime}-47^{\circ} 00^{\prime} \mathrm{W}\right)$, located in the municipality of ItanhaémSP/BR (SOUZA-PEREIRA and CAMARGO, 2004). According to these authors, this river is formed by the confluence of the Preto and Branco rivers, and has smaller tributaries, such as Guaú and Campininha. Almost all of the estuarine region is surrounded by an urban network, therefore being influenced by multiple anthropogenic impacts, including contamination from untreated domestic effluents (PINTO et al., 2015).

\subsection{Ethnobiological data collection}

A semi-structured questionnaire containing 107 questions (58 essay and 49 multiplechoice) was carried out based on the guidelines described by Selltiz (1974) and Boni and Quaresma (2005), using forms developed and applied by Fiscarelli and Pinheiro (2002) and Machado et al. (2018).

The interviews were only conducted after the participants read and signed an Informed Consent Form. All interviews were recorded, when authorized by the participant, for later retrieval of information during data transcription and analysis.

Due to the small number of licensed crab catchers in the Itanhaém Estuarine System (SEI), the interviewed sample was maximized by applying the Snowball sampling technique (HUDELSON, 1994; BERNARD, 2005), associated with the Local Mediator method (ALBUQUERQUE et al., 2010). Thus, the survey began from a single crab catcher registered at the Z-13 Padre José de Anchieta Fishermen's Colony (located in the Praia dos Pescadores beach), appointed as the key informant (local mediator), who was in charge of referring new contacts (HUDELSON, 1994). Each recruited individual was informed of new contacts with the desired characteristics from a personal catcher network, thus successively expanding the sample frame at each interview (BERNARD, 2005). The cycle ended with the saturation of information through the repetition of obtained names, without any new aggregation of data to the analysis framework.

In order to attract social representations (SR) and the perception of the crab catchers concerning the issues under study, the Collective Subject Discourse (CSD) method was applied, as recommended by Lefévre, Lefévre and Teixeira (2000), Minayo (2006), Dictoro et al (2016). This technique is based on the analysis of key expressions (literal transcriptions) and central ideas (essential discourse), aiming to reconstruct the collective and opinionated entity as a subject of discourse (first person singular), but linked to representation with collective and amplified content (LEFÉVRE and LEFÉVRE, 2006; DICTORO et al., 2016). 

(LINNAEUS, 1763): FISHERY PROFILE OF MANGROVE AREAS IN ITANHAÉM (SOUTHEAST BRAZIL)

The interviews took place from July to September/2017 in a location previously established by the crab catchers, covering two thematic axes, each comprising the following information: 1) capture and commercialization, dealing with the exploitation of the resource, choice of area, the period of capture, and forms of commercialization; 2) participatory environmental mapping (PEM), with representations of the mangrove areas used to capture the mangrove crab, categorization of extractive intensity, and other relevant information.

The PEM was elaborated using the information acquired from each crab catcher's knowledge and perception, based on the presentation of seven duly laminated maps of the Itanhaém Estuarine System (SEI), obtained from colored satellite images from Google ${ }^{\circledR}$ Earth. The maps were presented to each crab catcher for them to mark information on the capture areas, among other correlates, using pens for overhead projection. The first photographic map comprised a panoramic view of the SEI (Figure 1), while the others showed six properly enlarged areas of interest in the estuary $(A, B$, $\mathrm{C} 1$ and $\mathrm{C} 2$, D, and E). After being used for annotation by each crab catcher, the maps were then registered by digital photography for later analysis of their information. At the end, the photographic maps were cleaned with 70\% alcohol, dried, and shown to the next catcher. The information from each interviewee was compiled and gathered in a participatory map, using Google ${ }^{\circledR}$ Maps as a platform, where the polygons pertaining to the extraction areas were drawn and their areas duly established in the analyses.
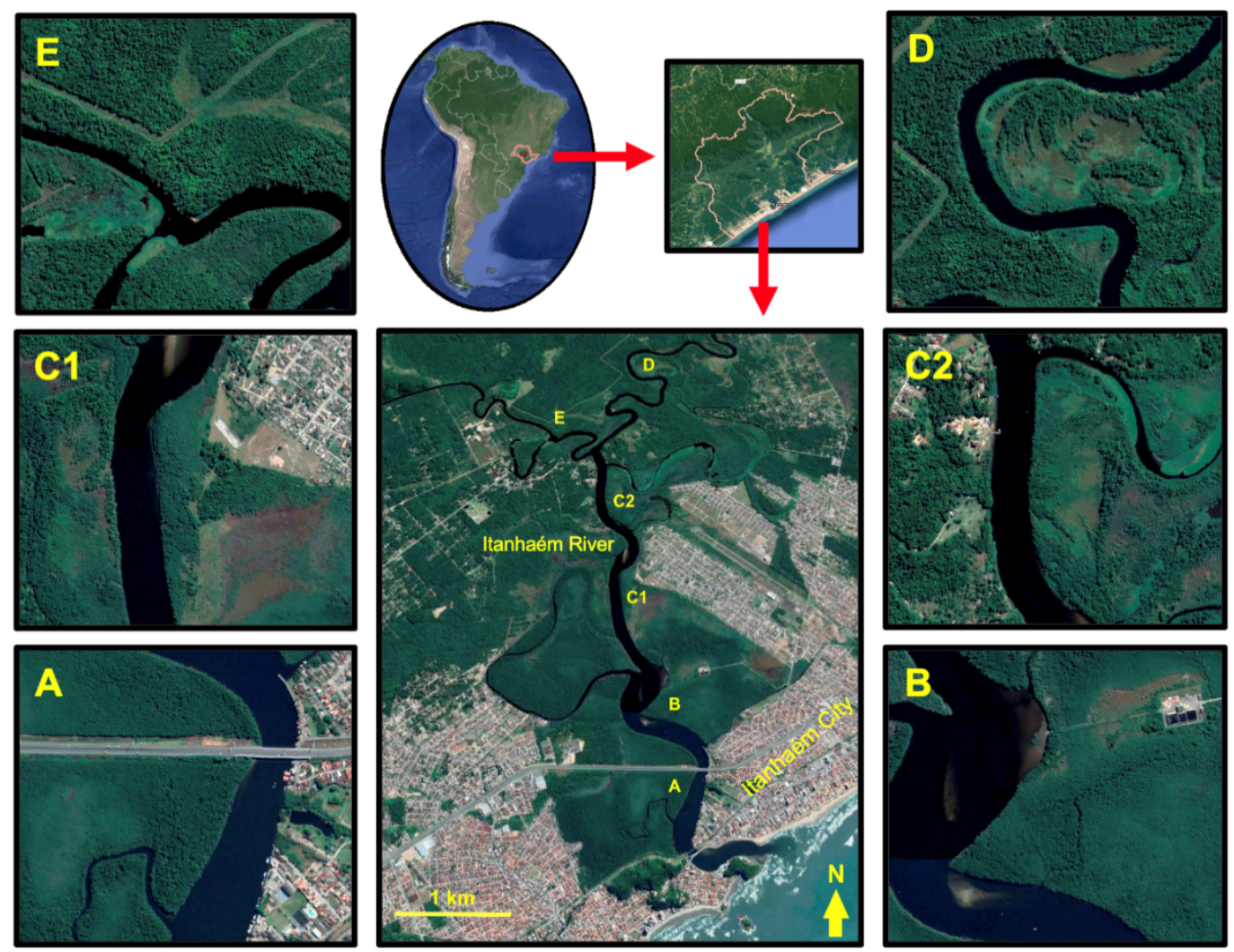

Figure 1: Photographic maps of the Itanhaém River Estuary (SP, Southeast Brazil) used to elaborate the participatory map of the mangrove crab capture sites and use intensity, presented to the crab catchers. General photographic map and the six properly enlarged areas of interest of the estuary (A, B, C1 and C2, D, and E) (Source: Modified from Google ${ }^{\circledR}$ Maps 2020 - Image from June 20, 2020). 
21 LOCAL ECOLOGICAL KNOWLEDGE (LEK) ON THE MANGROVE CRAB Ucides cordatus (LINNAEUS, 1763): FISHERY PROFILE OF MANGROVE AREAS IN ITANHAÉM (SOUTHEAST BRAZIL)

\subsection{Data analysis}

The present study was conducted using quali-quantitative variables, in which the quantitative information was classified, ordered, and metrically evaluated for a better understanding and comprehensiveness of phenomena. Meanwhile, the qualitative variables enabled the search for meaning attributed to these phenomena, with interpretation based on beliefs, opinions, and meanings, rendering the information neutral (VIEIRA, 2008). The quantitative data were obtained from the essay questions and typed in electronic spreadsheets that were duly tabulated, organized by themes, and arranged graphically. Meanwhile, the qualitative data was interpreted by direct quotes from the crab catchers, in addition to information from phrases obtained by the application of the Collective Subject Discourse (CSD) method, using the DSCsoft2.0 Software. This method was based on the analysis of key expressions and the central idea obtained from the interviews, generating a discourse that represents the collective idea on a given issue/theme (LEFÉVRE and LEFÉVRE, 2006; DICTORO et al., 2016).

The obtained quantitative data were entered in electronic spreadsheets, organized by theme, tabulated, and arranged graphically. When possible, the results were analyzed statistically by percentage values, as well as by minimum, maximum, mean, and standard deviation (SIEGEL and CASTELLAN, 1988; IHAKA and GENTLEMAN, 1996; SOKAL and ROHLF, 2003), in order to systematize the presentation and comparison of data. Some thematic axes had multiple and non-exclusive responses, explaining why some frequencies extrapolated $100 \%$ after being consolidated. Whenever possible, the data were compared with those available in the published data on the species.

\subsection{Ethical considerations}

The interviews were authorized by the Ethics Committee in Research with Human Beings of the State University of São Paulo (UNESP), Presidente Prudente Campus (CAAE: 69239817.8.0000.5402), and registered in the National System of Management of Genetic Heritage and Associated Traditional Knowledge (SisGen), under protocol $\mathrm{n}^{\circ}$ A894D3A.

\section{Results}

\subsection{Ethnobiological data collection}

The community of mangrove crab catchers of the Itanhaém Estuarine System (SEI) represents a small portion $(n=9)$ of the population of more than 100 thousand inhabitants. These individuals live in neighborhoods of up to 3 thousand inhabitants near the estuarine region, have low levels of education, and a mean family income of $\mathrm{R} \$$ $1,706.00 \pm 673.00$ or US\$ $317.10 \pm 125.09^{3}$, with the majority $(n=6)$ being associated with

\footnotetext{
${ }^{3}$ Considering the Commercial U.S. Dollar: US\$ $1.00=\mathrm{R} \$ 5.36$ on 05/05/2021.
} 
22 LOCAL ECOLOGICAL KNOWLEDGE (LEK) ON THE MANGROVE CRAB Ucides cordatus (LINNAEUS, 1763): FISHERY PROFILE OF MANGROVE AREAS IN ITANHAÉM (SOUTHEAST BRAZIL)

the Z-13 Padre José de Anchieta Fishermen's Colony (IBGE, 2017; see SOUZA and PINHEIRO, 2020).

A total of nine crab catchers were interviewed, $67 \%(n=6)$ of which had the General Fisheries Registry (RGP), while 33\% ( $n=3$ ) worked irregularly. Among all of the registered crab catchers, only two were active and had special authorization granted by SMA Resolution No. 64/2015 (SMA-SP, 2015), allowing them to extract the mangrove crab.

Of the total interviewed participants, $78 \%(n=7)$ did not teach artisanal crabbing to others due to misuse of the profession (predatory fishing), lack of demand, and because it is an unprofitable and undervalued activity by the local community. Two crab catchers mentioned teaching the trade to family and friends, many of whom accompany them during the catch. According to the Collective Subject Discourse (CSD), the central idea was professional devaluation.

I don't teach because of the misuse of the profession, due to predatory fishing. Nobody values it and no one wants to learn. It's difficult! - by four crab catchers.

I teach it only to family members and neighbors who sometimes accompany me - by two crab catchers.

\subsubsection{Capture and commercialization}

The interviewees cited the mangrove crab (Ucides cordatus) as the leading fishery resource, followed by commercially relevant fish (e.g., catfish, sea bass, and mullets) (Figure 2a). They also mentioned only two traditional methods of capture for mangrove crab, one of them being manual ("braceamento"; $n=9$ crab catchers) and the other by tangle-netting ("redinha"; $n=5$ crab catchers). Among the seven traditionally applied methods, "braceamento" and tangle-netting are used concomitantly by 56\% of the catchers.

Tangle-netting facilitates the animal's capture, especially during colder months, when they inhabit greater depths in the galleries; capturing them by "braceamento" (manually) during this period would cause injuries to the crab catcher's hands and arms. In the summer, due to the 'walk' (or 'gait') phenomenon, they state greater ease in capturing the crabs, dismissing the use of fishing gear and traps (such as the tangle net). Approximately $80 \%(n=4)$ of the crab catchers who use the tangle-netting technique set and retrieve the traps on the same day, whereas $20 \%(n=1)$ reported only removing the nets the next day. According to the CSD analysis, the central idea comprised the responsibility in using the tangle net.

I use the technique, but I collect all of the traps I set on the same day. I set them in the morning and retrieve them in the afternoon - by five crab catchers.

Among the total crab catchers, four learned the trade with friends, while the rest said they learned it from their father $(n=3)$, mother $(n=1)$, or by observing another catcher $(\mathrm{n}=2)$ (Figure $2 \mathrm{~b})$. Regarding tangle-net preparation, 56\% stated having learned the craft from friends $(n=5), 22 \%$ from their father $(n=2)$, and $22 \%$ through the observation of more experienced catchers $(\mathrm{n}=2)$, as shown in Figure 2c. 
23 LOCAL ECOLOGICAL KNOWLEDGE (LEK) ON THE MANGROVE CRAB Ucides cordatus (LINNAEUS, 1763): FISHERY PROFILE OF MANGROVE AREAS IN ITANHAÉM (SOUTHEAST BRAZIL)

The displacement of the crab catchers to the mangrove occurs mainly by canoe-like boats $(60 \%, n=6)$, which are made of wood and lack motorization ("bateras"), while the remaining $40 \%(n=4)$ travel on foot. Only one of the interviewees mentioned using both forms of locomotion.

According to the crab catchers, there are no particular rules for using the capture area $(44 \%, n=4)$, although three of them indicated that preference is given to the catcher who arrived first (Figure 2d). Meanwhile, for $28 \%$ of the catchers, the selected areas are those of lesser use ('fewer hits': 08 evocations) or greater abundance of crabs (21\%: 06 evocations) (Table 1).

Concomitantly, red mangrove forests (Rhizophora mangle) with muddy soil were preferred by $21 \%$ of the crab catchers (06 evocations each).

\section{EXPLOITED RESOURCES}

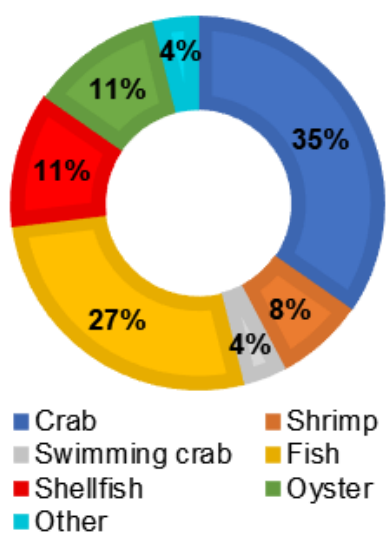

CAPTURE TECHNIQUES

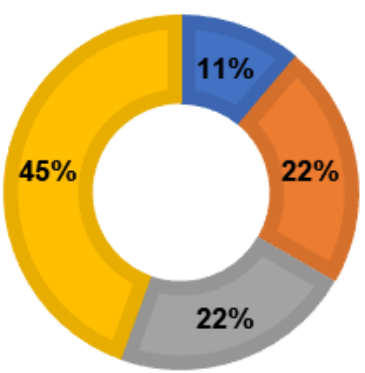

A

\section{RULES OF AREA USE}

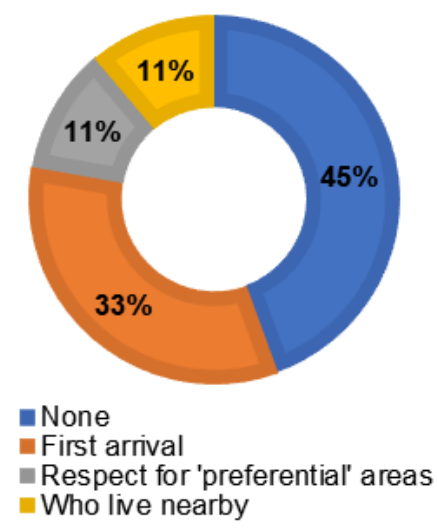

D
PREPARING THE 'REDINHA'

B

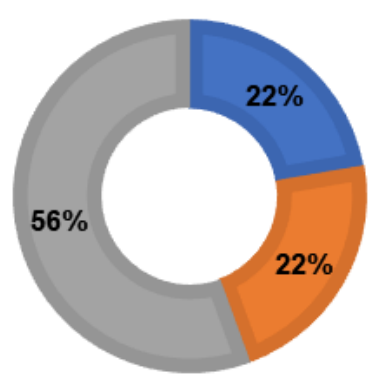

C

$\begin{array}{ll}\text { Mother } & \text { Father } \\ \text { Alone } & \text { Friends }\end{array}$

Figure 2: Summary of the exploited resources, rules of capture area use, and the people responsible for the transfer of knowledge on capturing techniques and how to prepare the tangle net. Source: created by the authors. 
24 LOCAL ECOLOGICAL KNOWLEDGE (LEK) ON THE MANGROVE CRAB Ucides cordatus (LINNAEUS, 1763): FISHERY PROFILE OF MANGROVE AREAS IN ITANHAÉM (SOUTHEAST BRAZIL)

Table 1: Criteria used by the artisanal fishermen for the selection of mangrove crab (Ucides cordatus) capture areas in the Itanhaém River Estuary (SP, Brazil). Source: created by the authors.

\begin{tabular}{ccc}
\hline Capture area selection criteria & Evocations (\%) & Overall (\%) \\
More or less hit areas & 89 & 28 \\
Greater abundance & 67 & 21 \\
Type of vegetation (red mangrove) & 67 & 21 \\
Type of soil (muddy) & 67 & 21 \\
Type of vegetation (white mangrove) & 11 & 3 \\
Type of soil (sandy) & 11 & 3 \\
\hline
\end{tabular}

All of the catchers mentioned rotating among the capture areas, obeying weekly, monthly, or even annual intervals in order to increase the abundance and size of the crabs, as well as not to exhaust the resource, since they depend on it for survival. The largest percentage of crab catchers $(43 \%, \mathrm{n}=6)$ conducts a monthly rotation (mean \pm standard deviation: $65 \pm 40$ days); $28 \%(\mathrm{n}=4)$, a weekly rotation (9 \pm 4 days); $21 \%(\mathrm{n}=3)$ rotate every $2 \pm 1$ days; and 7\% (n=1), annually. From the CSD point of view, the central idea consisted of the temporal variation and preservation of the crab.

It varies a lot because of the large area, from two days to a week, or from three to four months to a year, but if it's good, on the next day - by five crab catchers.

Every hour I go to a given place according to the size and number of animals in the area. I try to return there a week up to three months later in order not to deplete the crab population, to preserve it, to avoid shortage - by nine crab catchers.

The surveyed catchers stated that the best period for capturing mangrove crab is from November to March due to the greater ease in capture and commercialization, coinciding with the 'walk' of this species (greater activity outside the galleries) during the summer holidays, which renders marketing more viable. As the central idea, spring and summer constitute the reproductive period, as stated in the CSD.

At the end of the year, during the high season. It's part of the mangrove, the crabs are running, they come out of their burrows to breed, there are a lot of crabs, they become easy to catch and sell - by nine crab catchers.

The third quarter and full moons were cited as the most effective for crab catching by $35 \%$ of the crab catchers, followed by the new moon (21\%) and first quarter (7\%). Also, $90 \%$ of them indicated low tides as the most suitable for mangrove crab catching (Figure 3a). The central idea around this issue was that the crabs are easier to capture when there is a full moon and low tides.

During a full moon since, when they leave their burrows, they're easier to catch - by two crab catchers.

The tide doesn't enter the mangrove, so I have more time to catch the crabs. It dries up and you can see the burrows and the traps. In the quarter moon it's not as good because the tide is high - by eight crab catchers. 
MOON PHASES AND TYPE OF TIDES

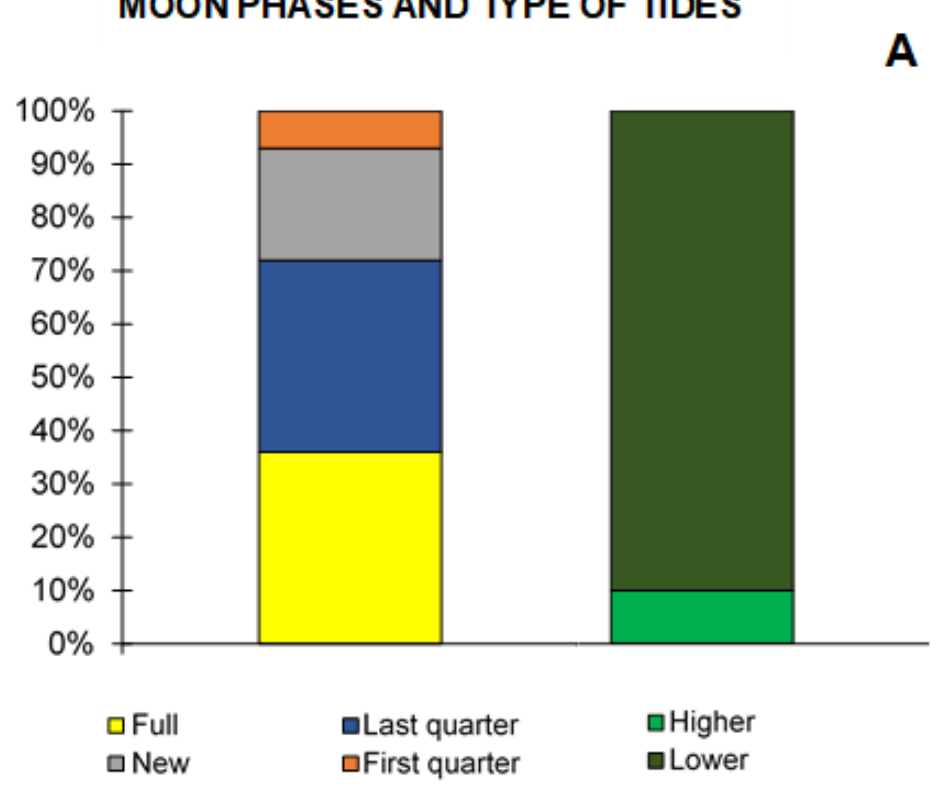

\section{OBSTACLES}

B

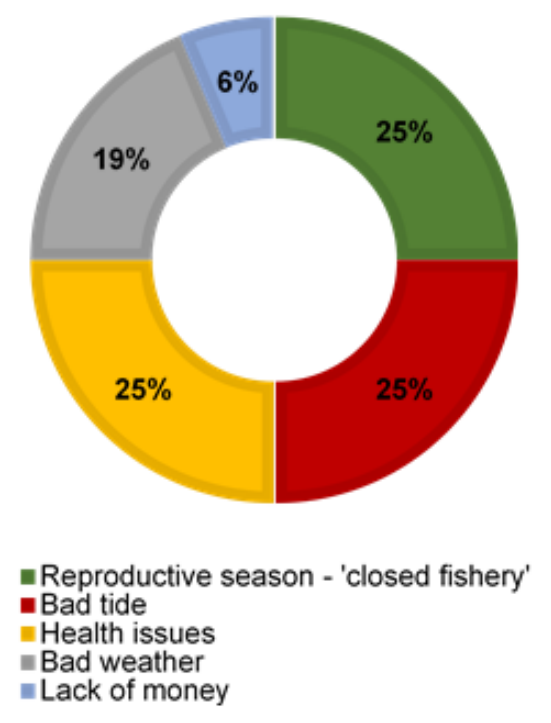

Figure 3: Summary of the optimal lunar phases, the preferred types of tide, and encountered obstacles by the mangrove crab (Ucides cordatus) catchers when using the mangroves of the Itanhaém River (SP). Source: created by the authors.

During low tides, crab catchers work $5 \pm 3$ hours/day, with a visitation frequency of $4 \pm 2$ times/week to the mangrove; however, $20 \%$ of them capture the animal monthly, at most 2 times/month. According to the interviewees, the frequency of visits to the mangrove can be hampered due to the occurrence of the closed season for mangrove crab capture, 'bad tides', or when they are sick (25\% each), although they also mentioned bad weather (19\%) and not needing money on that day (6\%) as reasons. Other additionally cited factors include molting (shell) of the crab (milk crab) and 'biting midge' season (Figure 3b). 
26 LOCAL ECOLOGICAL KNOWLEDGE (LEK) ON THE MANGROVE CRAB Ucides cordatus (LINNAEUS, 1763): FISHERY PROFILE OF MANGROVE AREAS IN ITANHAÉM (SOUTHEAST BRAZIL)

The crab catchers qualified the working days according to the number of crabs caught per catcher (crabs/catcher) as: 1) 'normal' day, with $107 \pm 40 \mathrm{crabs} / \mathrm{catcher}$ (5-15 dozens/catcher); 2) 'good' day, in favorable moon and tidal conditions, with $216 \pm 163$ crabs/catcher (10-50 dozens/catcher); and 3) 'bad' day, in bad weather conditions, with $44 \pm 29 \mathrm{crabs} /$ catcher (2-7 dozens/catcher).

The selection of crabs by the catchers followed three main rules, with $29 \%$ of evocations each: 1) compliance with the minimum capture size (CW, carapace width $>6 \mathrm{~cm}$ ); 2) not to capture ovigerous females; and 3) not to capture females, even without eggs. At lower percentages, there was also a maximum catch limit/day (6\%) and catching on demand (6\%) (Figure 4a). These rules were established by the crab catchers themselves (58\%) or by inspection agencies that supervise this fishery resource (42\%), whose capture is centered only on males, with sizes (CW) ranging from 6 to $8 \mathrm{~cm}(7.6 \pm 1.4 \mathrm{~cm})$.
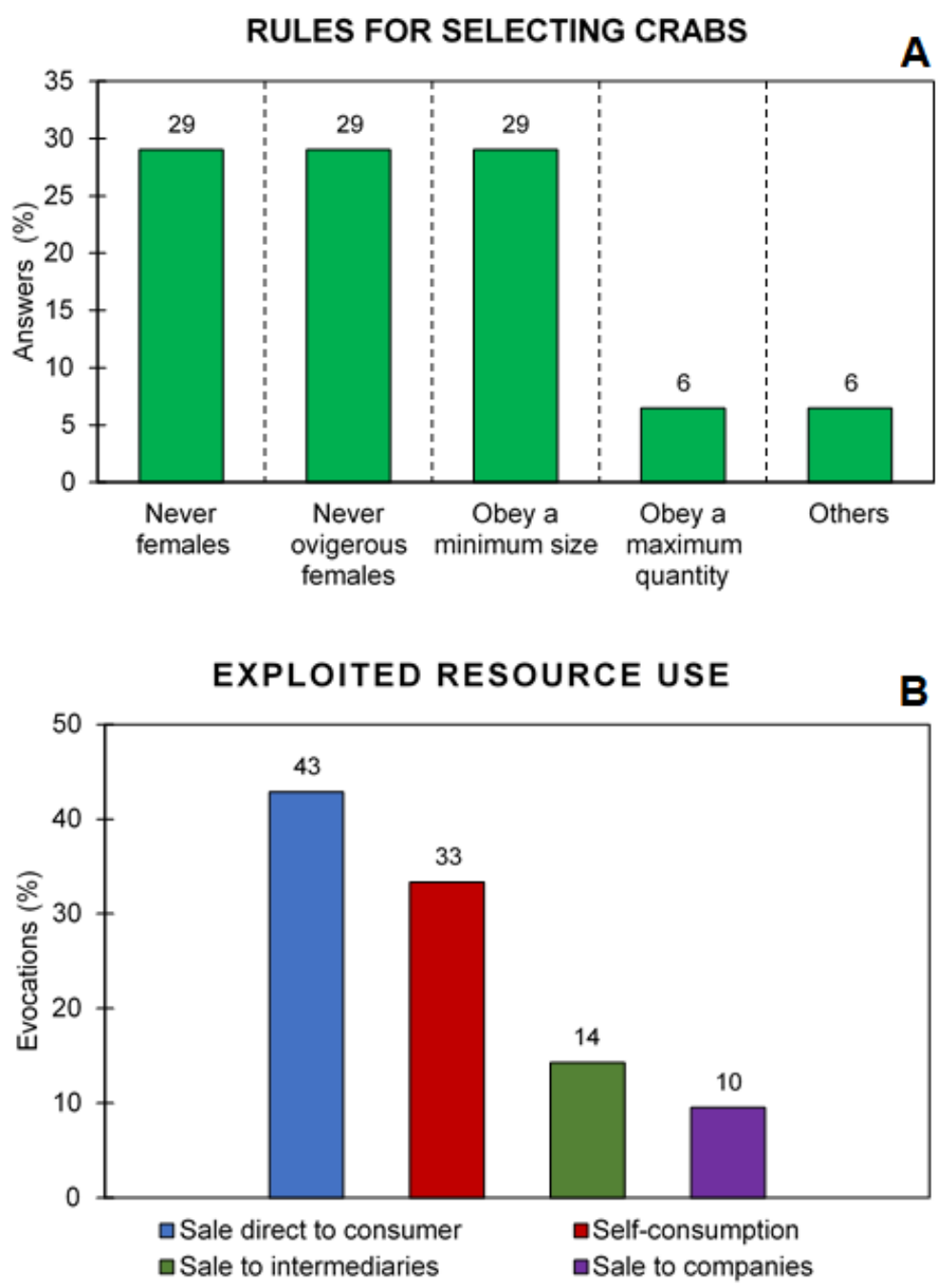

Figure 4: Rules for mangrove crab (Ucides cordatus) selection by the crab catchers of the Itanhaém River Estuary (SP, Southeast Brazil) and its destination. Source: created by the authors. 


\section{FREQUENT BUYERS}

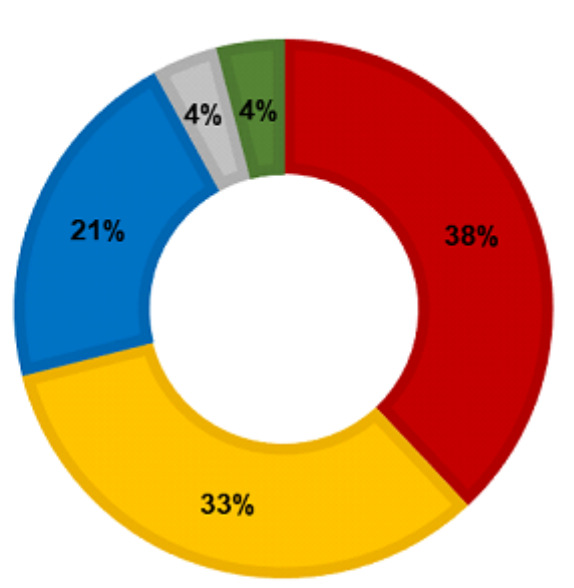

AVERAGE PRICE BY BUYERS

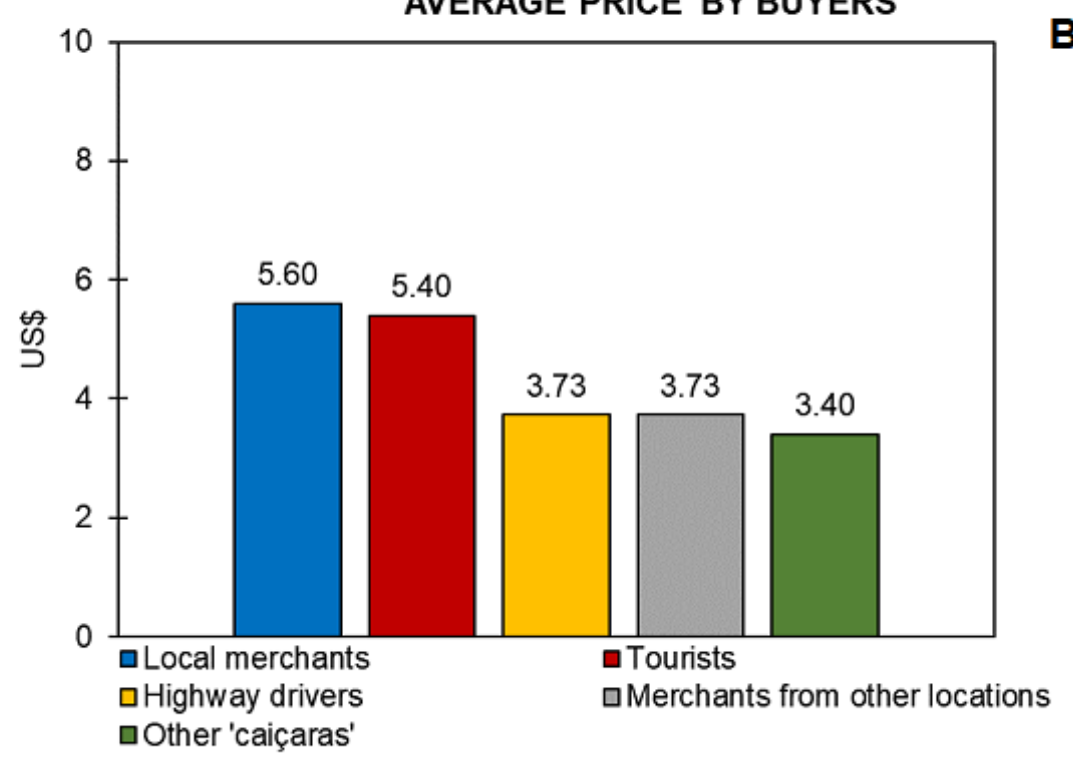

A

B

Figure 5: Most frequent buyers and average selling price of the mangrove crab (Ucides cordatus) by crab catchers in the Itanhaém River (SP, Southeast Brazil). Source: created by the authors.

Considering the use of the resource, $90 \%$ of the interviewees stated that the crabs were sold/commercialized alive. Most of them (76\%) use the animals for their own consumption or sell them directly to the consumer (at the fish market or by order), while the remaining $24 \%$ are destined to intermediaries or companies in the region (e.g., kiosks and restaurants) (Figure 4b).

The crabs were sold alive (90\%) or frozen (10\%), being stored in plastic bags (10\%), and never sold fresh (on ice). The product is marketed intact (75\% of the crab catchers), although $25 \%$ mentioned selling the processed meat in plastic bags, without the sale of only the "pincers" (1st pair of chelated legs of the crab) alone. Marketing in dozens is the most practiced method by crab catchers (90\%), although some sell them in units (10\%).

The main buyers of crabs were tourists (38\%), followed by the community (33\%) and local merchants (21\%), with the remaining $8 \%$ destined for foreign merchants and 
28 LOCAL ECOLOGICAL KNOWLEDGE (LEK) ON THE MANGROVE CRAB Ucides cordatus (LINNAEUS, 1763): FISHERY PROFILE OF MANGROVE AREAS IN ITANHAÉM (SOUTHEAST BRAZIL)

drivers circulating on the highway (BR-101), with 4\% each (Figure 5a). The price ${ }^{4}$ per 'rope' (a dozen crabs) for tourists was higher (US\$ 3.00 to 8.00/dozen; US\$ $5.40 \pm$ 2.00/dozen) than for "caiçaras" (US\$ 3.00 to 5.00/dozen; US\$ $3.40 \pm 2.00 /$ dozen) (Figure $5 b)$.

According to one interviewee, all crab catchers are male, with women being responsible for cleaning or processing the collected animals. In addition, $60 \%$ of the crabbing activity occurs individually and, when accompanied, the collaborator (partner) is usually a brother or friend (30\%), and the obtained profit is divided among them.

Most of the crab catchers go hunting at a specific time of the year $(78 \%, n=7), 44 \%(n=4)$ catch crab outside the closed season and 33\% (n=3) during the closed season. Among the total crab catchers, $22 \%(n=2)$ did not declare a specific period of crabbing, given that capture occurs on demand.

\subsubsection{Participatory Environmental Mapping (PEM)}

The participatory mapping of mangrove crab fishing highlighted the primary catching areas in the Itanhaém River Estuary (SP), as well as other relevant information obtained at the time of mapping (Figure 6). After the six maps were presented to the crab catchers, four mangrove crab capture zones were established: Zone A, B-C1, C2, and D-E. In them, the catchers pointed out different locations in the mangrove, which were categorized according to intensity of use and, subsequently, each one was discriminated according to occupation area (in hectares - ha).

In Zone A (Figure 6), located in the portion below the Padre Manoel da Nóbrega Highway (SP-55, km 6), the mangroves identified by the catchers generated an area of 58.1 ha (red polygon) that was very close to the estuarine mouth $(0-1.7 \mathrm{~km})$ and the urban network, with intense crab catching (reported by $70-100 \%$ of the interviewees). Zone B-Cl, located in the portion above the SP-55 highway, between 1.7 and $3.7 \mathrm{~km}$ from the mouth of the estuary, totaled 72.6 ha of mangroves used by the crab catchers, comprising six polygons belonging to three categories of capture intensity, as follows: 1) intermediate capture (03 orange polygons: $50.4 \mathrm{ha}$ ), by 40-70\% of the interviewees; 2) moderate capture (yellow polygons: 18.3 ha), by $10-40 \%$ of the interviewees; and 3) low capture (light blue polygons: 3.9 ha), by $\leq 10 \%$ of the interviewees.

\footnotetext{
${ }^{4}$ Considering the Commercial U.S. Dollar: US\$ $1.00=\mathrm{R} \$ 5.36$ on 05/05/2021.
} 
29 LOCAL ECOLOGICAL KNOWLEDGE (LEK) ON THE MANGROVE CRAB Ucides cordatus (LINNAEUS, 1763): FISHERY PROFILE OF MANGROVE AREAS IN ITANHAÉM (SOUTHEAST BRAZIL)
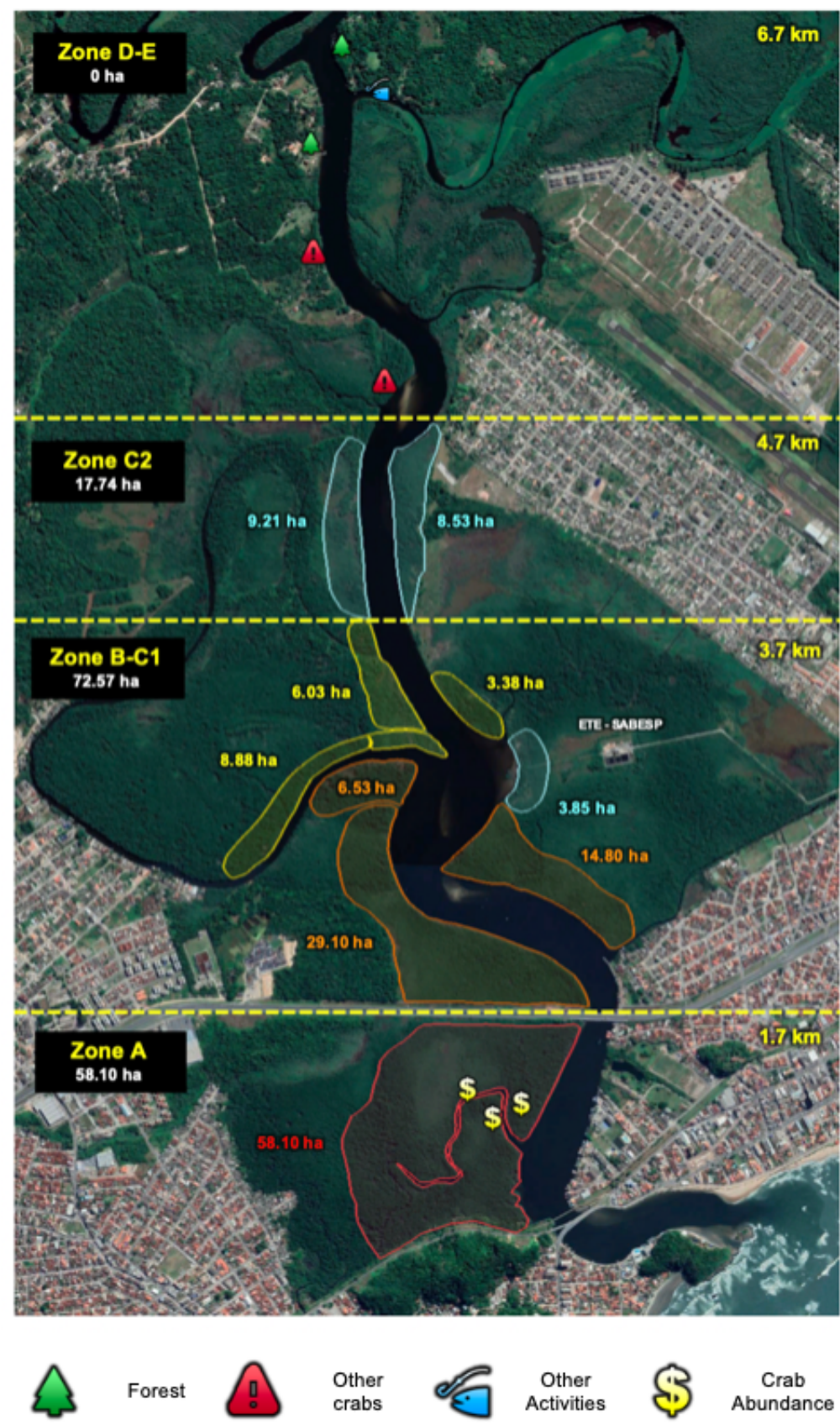

Figure 6: Capture map of the mangrove crab (Ucides cordatus), designed using information obtained during interviews with crab catchers of the Itanhaém River, in the municipality of Itanhaém (SP, Southeast Brazil), through the participatory mapping technique. Each capture area was classified in function of its crab use, as: intense (red areas, 70$100 \%$ ); intermediate (orange areas, 40-70\%); moderate (yellow, 10-40\%), and low (light blue, $\leq 10 \%$ ) (Source: created by the authors from an image generated by Google ${ }^{\circledast}$ Maps 2020).

\section{Discussion}

\subsection{Ethnobiological data collection}

Traditional fishing communities, especially those of small size (e.g., the present study), have sustained different pressures that have suppressed their activity or existence, with science being the safeguard of their memory, recording that they once existed. In the study by Namora et al (2009), the authors mentioned only basal elements regarding mangrove crab capture. In 2020, Souza and Pinheiro depicted the socioeconomic profile 

(LINNAEUS, 1763): FISHERY PROFILE OF MANGROVE AREAS IN ITANHAÉM (SOUTHEAST BRAZIL)

of this artisanal fishermen's community and their perceptions regarding the conservational status of the mangrove and its habitat. In contrast, the present study had the priority of gathering original information on the remaining "caiçara" crab catchers of the region, as well as their traditional knowledge on capturing, manipulation, commercialization, and capture areas, outlining their activity, thus contributing to the management and administration of this fishery resource.

The reliability of the obtained data reflects the mutual trust necessary to carry out studies of this nature, seeing that it involved impersonality, secrecy, and an absence of links with inspection agencies (DUARTE, 2004). According to this author, such premises are essential since many of the developed surveys occur in areas influenced by drug trafficking (MACHADO et al., 2018), thus requiring the proper receptivity on the part of the crab catchers in order for them to feel valued and, therefore, provide information in a serious and cordial manner. Crab catchers comprise a socioeconomically marginalized population with low levels of education (ALVES and NISHIDA, 2004; NORDI et al., 2009), a fact that hampered the study's execution, especially in the case of female interviewers when obtaining data from crab catchers, who, in Brazil, are generally of the male sex (RODRIGUES et al., 2000; ALVES et al., 2005; FREITAS et al., 2015).

The community of crab catchers in the municipality of Itanhaém presented a dimension incompatible with that provided by their class entity (Z-13 Fishermen's Colony), evidencing their low representativeness, as the number of interviewees exceeded the previously informed contingent of crab catchers by $80 \%$. Despite the small number of respondents, the present study provides essential information on the universe of crab catchers in the Itanhaém Estuarine System (SEI), which are crucial for the management and preservation of $U$. cordatus and the mangroves, given the traditional knowledge they hold and their direct involvement with the fishery resource and its habitat. The present study may represent the only (possibly the last) record of this region's customs and the activity of the Brazilian "caiçaras".

Crab catching is one of the oldest extractive activities in Brazil (IBAMA, 1994), with basal origin in indigenous communities, having gradually become extinct in the studied region, a fact confirmed by the disinterest of $80 \%$ of the crab catchers in transferring their knowledge on this subject to their descendants. This fact is aggravated by large urban centers (e.g., Rio de Janeiro - see CORTÊS et al., 2014), maintaining itself as a tradition and culture in more remote areas of the country (e.g., Pará, Paraíba, and Bahia - see COSTA-NETO and GORDIANO-LIMA, 2000; ALVES and NISHIDA, 2004; GLASER and DIELE, 2004; FREITAS et al., 2015). The crab catchers have been encouraging their children to dedicate themselves to studies and other more profitable activities, interrupting cultural transfer within the family, which is the basis for perpetuating popular knowledge (ALVES and NISHIDA, 2002). Thus, only in the Brazilian North and Northeast have the extraction and commercialization of meat been valued, although this is not the main product extracted from the crab, which is also used for medicinal purposes (COSTA-NETO and GORDIANO-LIMA, 2000), a cultural loss already occurring by the crab catchers in Itanhaém. 

(LINNAEUS, 1763): FISHERY PROFILE OF MANGROVE AREAS IN ITANHAÉM (SOUTHEAST BRAZIL)

\subsubsection{Capture and commercialization}

The mangrove crab is the primary source of resources for crab catchers, who also devote secondary efforts to other crustaceans, fish, and mollusks, which are common in mangroves where juveniles of these species live, safeguarding their importance as life nurseries (SCHAEFFER-NOVELLI et al., 2016; SOUZA et al., 2018). Therefore, the compromised health and balance of this ecosystem lead to broader ecological imbalances, which affect other species used as a source of income and support for crab catchers (VIDAL and SASSI, 1998).

Along the Brazilian coast, several techniques are described for capturing the mangrove crab (PINHEIRO and FISCARELLI, 2001; SOUTO, 2007; NORDI et al., 2009), which are transferred empirically, being endogenous to certain communities and that may undergo adaptations. Thus, most crab catchers do not use only one but a range of techniques, according to local circumstances and specificities (LEGAT et al., 2006; MACHADO et al., 2018). In Itanhaém (SP), the "braceamento" technique (see PAIVASOBRINHO and ALVES, 2000) is used without any protection for the crab catcher's skin, requiring significant effort and with frequent abrasions/cuts to the arms/hands. This situation is aggravated during the growth period (molting) of $U$. cordatus when the crabs go deeper into their burrows and catchers are required to use the tangle-netting technique to capture them, a fact that was $40 \%$ greater than that recorded in Iguape and Cubatão (SP) (FISCARELLI and PINHEIRO, 2002; MACHADO et al., 2018). However, 80\% of the crab catchers in Itanhaém are concerned about the possible deaths of crabs in these traps if they remain trapped for more than a day, thus retrieving them a few hours after setting the traps, as occurs in other Brazilian regions (BOTELHO et al., 1999; BARBOZA et al., 2008; COSTA-NETO et al., 2010; MAGALHÃES et al., 2011).

The substitution of the "braceamento" technique by tangle-netting represents a break with the typical patterns of extraction of this species (ALVES and NISHIDA, 2002) since the first is traditional and the second is considered an alternative method. In this sense, a substantial loss in the rich repertoire of theoretical and practical information on the biology of the species can be noted, with subsequent losses to management, conservation, and sustainable use, based on experience. It is important to highlight that such teachings have been transferred over generations since their origin by the indigenous people of the Tremembé (BA, Northeast Brazil) area (COSTA-NETO et al., 2010; MAGALHÃES et al., 2011; FREITAS et al., 2015). Thus, the offering of personal protective equipment (PPE) to crab catchers (e.g., protective clothing, boots, gloves, etc.) could minimize physical damage to users of the "braceamento" technique and reduce the use of the tangle net. However, these items would need to be more accessible, either by financing (fishery colonies) or free of charge (federal agencies).

Around $44 \%$ of the crab catchers mentioned that there is no rule for the use of mangroves for capture in Itanhaém ("rules for area use", according to THÉ and NORDI, 2006), while $33 \%$ stated that priority is given to the first crab catcher who arrived at the location, as reported by Machado et al. (2018) in Cubatão (SP). The crab catchers of Itanhaém, like those in Cubatão (SP), prefer less "hit" areas, where crabs are more abundant, due to the greater influence of the tides, silt sediment, and predominance of red mangroves (Rhizophora mangle), a fact confirmed by $11 \%$ of the crab catchers from Iguape (SP) (FISCARELLI and PINHEIRO, 2002). Several authors point out the strong association of these factors on $U$. cordatus (COSTA, 1979; DIELE, 2000; ALVES and 

(LINNAEUS, 1763): FISHERY PROFILE OF MANGROVE AREAS IN ITANHAÉM (SOUTHEAST BRAZIL)

NISHIDA, 2004), although Pinheiro and Fiscarelli (2001) stated that the density of this species varies extensively in mangroves due to its level of preservation and extractive intensity. Duarte et al. (2016), for example, found that the increase in solid wastes (garbage) in these environments can halve the density of $U$. cordatus in relation to pristine mangroves, a fact confirmed by the crab catchers of Itanhaém (SP).

The rotation of the mangrove area by the crab catchers in Itanhaém (SP) is possibly related to their concern with its reduced size (375 ha, according to AMARAL et al., 2006; SANTOS and FURLAN, 2010). Its area is six times smaller than the Cubatão mangroves (2,300 ha), where $76 \%$ of the crab catchers are not concerned with this type of management (MACHADO et al., 2018).

According to the interviewees, the five months associated with the 'walk' of the mangrove crab (spring-summer), which coincide with the main holiday season, facilitate the capture and commercialization of this resource, confirming the data reported by Machado et al. (2018) and Souto (2007). Nonetheless, these authors mention that the primary reproductive events of the species also occur in that period (e.g., gonadal maturation and embryonic/larval development - see PINHEIRO and FISCARELLI, 2001), which was considered pejorative by half of the crab catchers of Várzea Nova (PB, Northeast Brazil) (NORDI, 1994). Moreover, the catchers who sustain more injuries at this time (e.g., oysters attached to the mangrove roots) also imply lower values in the trade of this resource due to increased capture. Such contrast indicates that the crab catchers' socioeconomic condition alters their behavioral actions in relation to the resource, depending on the Brazilian region, even if it encompasses the species' closure period.

The capture of the mangrove crab, according to the interviewed crab catchers, is maximized in third quarter and full moons (35\% each), followed by the new moon (21\%), and is related to two aspects: 1) more time available to capture the crabs in quarter moons (first and third) due to smaller tide amplitude, which is enhanced in full and new moons (NORDHAUS et al, 2009) and 2) less abundance of hematophagous mosquitoes or 'biting midges' in quarter moons (LUTZ, 1912; FORATTINI et al., 1958), which are influenced by the synodic lunar cycle (SCHMIDT et al., 2012), reducing discomfort during mangrove crab catching (FISCARELLI and PINHEIRO, 2002; NORDHAUS et al., 2009). According to Machado et al. (2018), crab catchers in Cubatão (SP) also showed a greater preference for third quarter moons (64\%) than full and new moons (29\% each), stating also preferring more extended periods of low tides due to the easier localization of crab galleries and the lower incidence of 'biting midges'.

The frequency of visitation by the crab catchers to the mangrove (2-4 times/week), of on average 5 hours/day, was similar to the data found in Cubatão (SP) by Machado et al. (2018), with the length of stay depending on tide amplitude, climatic conditions, the presence of 'biting midges', and according to the demand for sale or consumption by the crab catchers themselves. The average daily catch (crabs/catcher) depends on climatic conditions and local demand, ranging from 4 to 18 dozen, corroborating Machado et al. (2018). In Iguape (SP), on the other hand, Fiscarelli and Pinheiro (2002) reported a higher frequency of visitation to the mangroves (6 times/week/catcher), with similar catch averages between winter and summer (10 to 11 dozen/day/catcher, respectively). 

(LINNAEUS, 1763): FISHERY PROFILE OF MANGROVE AREAS IN ITANHAÉM (SOUTHEAST BRAZIL)

It was noted that IBAMA Ordinance No. 52/2003 (IBAMA, 2003) has been partially respected by the crab catchers of Itanhaém (SP) since, although they do not capture animals below the established minimum size $(C W>6 \mathrm{~cm})$ and females (especially ovigerous ones), they use traps that are prohibited by law (tangle-netting). The females of $U$. cordatus are captured in some Brazilian regions, but only those of larger size and when the males are scarce, and are generally consumed by the crab catchers themselves and their families (NORDI, 1994; SOUTO, 2007). The non-capture of females in Itanhaém (SP) is possibly due to the reduced competition between crab catchers, who respect the legislation in force (IBAMA, 2003; SMA-SP, 2015). Around 60\% stated that the current crabbing laws resulted from a process of participatory management carried out from 1998 to 2003 (see RODRIGUES et al., 2000), a fact confirmed by 73\% of the crab catchers in Cubatão, SP (MACHADO et al., 2018).

After being caught, the crabs are usually kept alive in the crab catchers' houses in Itanhaém (SP) until commercialization, thus reducing mortality, which has been a recurring concern in some Brazilian regions where the transport of these animals is mandatory in hollow plastic boxes ("basquetas"), according to EMBRAPA specifications established in MPA Normative Instruction No. 09/2013 (MPA, 2013). In general, this type of transport is uncommon in the State of São Paulo, which would effectively reduce losses by transport mortality by approximately 10-fold.

None of the crab catchers in Itanhaém sell isolated parts of the crab (e.g., 'pincers' or chelipeds), although some have stated conducting crab meat processing ('stuffing'), which evidences a certain dissonance with the legislation due to the strict sanitary and microbiological guidelines (ANVISA, 2019) that regulate this activity. Conversely, meat processing is a common activity in the Brazilian North and Northeast, where even young and female crabs are used in the production of the 'stuffing', which has been decreasing the natural stocks of the species and causing serious public health problems related to the bacterial contamination of this food due to inappropriate handling (FREITAS et al., 2015; NASCIMENTO et al., 2016; PINHEIRO et al., 2017).

The use of the tangle-netting method by crab catchers in Itanhaém (SP) did not maximize the capture of the crustacean between the days considered 'normal' and 'good', rendering 40\% less yield than the use of the "braceamento" technique, contrasting with the data obtained by Jankowsky et al (2006), who indicated the tangle net as being responsible for the increase in the capture effort in Cananéia (SP). However, the knowledge and practical experience of crab catchers can be the explanatory variable for understanding such divergences since, before carrying out the "braceamento" technique, some catchers are able to direct efforts to the male galleries, either through their wider opening or by observing the tracks in the adjacent sediment, which are deeper and 'brushed' by the bristles in specimens of this sex (see SANTOS et al., 2009). In addition, those who use the tangle-netting method when capturing demand more time, either in trap preparation or its installation and retrieval, with losses in the process, as they are not always able to locate where all the traps were set, although more experienced crab catchers do this with ease. Another relevant fact is that the technical differences in the capture of $U$. cordatus, particular to each community of crab catchers, did not reflect in a significant contrast in the commercialization prices practiced in Itanhaém (present study) and Cubatão (Central Coast: US\$ 6.00 to 9.00/dozen) (MACHADO et al., 2018), which were slightly higher than 
34 LOCAL ECOLOGICAL KNOWLEDGE (LEK) ON THE MANGROVE CRAB Ucides cordatus (LINNAEUS, 1763): FISHERY PROFILE OF MANGROVE AREAS IN ITANHAÉM (SOUTHEAST BRAZIL)

those registered for the Southern Coast (Iguape: US\$ 4.00 to 8.00/dozen) (FISCARELLI and PINHEIRO, 2002).

This significant decrease (40\%) in the fishing production of the mangrove crab in Itanhaém in the 2017-2018 biennium may be related to the reduction of the local fishery stock due to anthropic impacts and/or a decrease in this activity on account of other more profitable options, developed in parallel. Considering the limited contingent of crab catchers with special licenses in this municipality, and that $78 \%$ of the crab catchers in Itanhaém (SP) work illegally (without special authorization), it is possible to infer that the risk on the species and mangrove is even higher. This fact shows that evaluations such as these are extremely relevant to readjust the number of special licenses in a particular region of coverage, as in the case of the Central Coast of the State of São Paulo (SMA-SP, 2015), which would favor professionals who work illegally due to the absence of prior registration.

\subsubsection{Participatory Environmental Mapping (PEM)}

The elaboration of the Participatory Environmental Mapping (PEM) for the SEI enabled us to verify the reduced mangrove area in the municipality of Itanhaém (375 ha), which corresponds to roughly $3 \%$ of this ecosystem in the Baixada Santista area (12,021 ha), covering a range $<6.7 \mathrm{~km}$ from the estuarine mouth (AMARAL et al., 2006; SANTOS and FURLAN, 2010). According to the PEM-SEI, local crab catchers use $40 \%$ (148.4 ha) of the total mangrove area in the municipality, 86\% (126.9 ha) of which were considered to be intermediate to intense capture areas. Additionally, the largest mangrove areas where the crab catchers are most active are closer to the estuarine mouth, decreasing with distancing towards the continent, which may be due to the significant ease of access and because they are areas of estuarine margin (mangrove 'fringe'), where larger crabs are found and in greater abundance (WUNDERLICH et al., 2008; PINHEIRO and ALMEIDA, 2015). It was also possible to identify the negative impacts of local anthropic activities, such as the discharge of domestic effluents and the suppression of riparian forests (PINTO et al., 2015; RIZZO, 2007; ALVES and QUIÑONES, 2013), mainly in Zone B$\mathrm{Cl}$, which can certainly reduce the population abundance of the mangrove crab. Furthermore, we observed that the mangrove areas in the SEI are smaller in the upper stretch, $4.7 \mathrm{~km}$ from the mouth, where they are replaced by other phytophysiognomies (e.g., Atlantic Forest and "Restinga").

In the present study, the CSD revealed the essence of the responses of the Itanhaém crab catchers, giving life, voice, and meaning to what statistics often cannot translate, but which was built on real experiences, obtained by empirical knowledge. The PEM, in turn, is a fundamental instrument for future management actions aimed at the preservation of $U$. cordatus and mangroves, bearing specific information and details, adding traditional knowledge, in a transparent and systematic way (ANUCHIRACHEEVA et al., 2003; GERHARDINGER et al., 2009). The use of the generated data in environmental management and participatory planning is clear, based on more attractive and practical tools for interpretation, discussion, and effective propositions. 
35 LOCAL ECOLOGICAL KNOWLEDGE (LEK) ON THE MANGROVE CRAB Ucides cordatus (LINNAEUS, 1763): FISHERY PROFILE OF MANGROVE AREAS IN ITANHAÉM (SOUTHEAST BRAZIL)

\section{Conclusions}

The mangrove crab catchers from Itanhaém (SP) show, both behaviorally and cognitively, an attitude of respect towards the local mangrove. The interaction of these professionals with the mangroves and this fishery resource, combined with other variables of their perception and knowledge (e.g., lunar phases, tidal regimes, mangrove flooding times), help to better understand the abundance and fishing of this crustacean. This ethnobiological information can prioritize actions to improve the quality of life of these professionals, as well as the management of the mangrove crab and the mangroves themselves. Man and nature coexist in space; therefore, they must be managed in a unique, responsible, and sustainable way. These data indicate gaps to be filled regarding the regularization and inspection of this fishing activity. Also, there is a need for a representative agency in the category, working closely and more actively for the benefit of the crab catcher, especially regarding the transfer of essential information in their activity, thus promoting a better quality of life.

\section{Acknowledgements}

The authors would like to thank the mangrove crab catchers of the Itanhaém River Estuarine System (SEI) for their life lessons, respect, and welcome, hoping that the study can bring better knowledge to management and supervisory agencies, as well as to the production process as a whole. They also thank the Z-13 Padre José de Anchieta Fishermen's Colony for the availability of data and help when required, and the members of the 'Crustacean Biology Research Group' (CRUSTA) for their assistance, when requested, during the analyses carried out at the 'Laboratory of Biology for the Conservation of Crustaceans', at UNESP IB/CLP. MAAP especially thanks the National Council for Scientific and Technological Development (CNPq) for the awarded research fellowship grants (\#303286/2016-4 and \#305957/2019-8).

\section{Referências -}

Albuquerque, U. P.; LUCENA, R. F. P.; CUNHA, L. V. F. C. Métodos e técnicas na pesquisa etnobiológica e etnoecológica. Recife: NUPEEA, 2010. 204 p.

ALVES, R. R. N.; NISHIDA, A. K. A ecdise do caranguejo-uçá Ucides cordatus L. (Decapoda, Brachyura) na visão dos caranguejeiros. Interciência, v. 27, n. 3, p. 110-117, 2002.

ALVES, R. R. N.; NISHIDA, A. K. Population structure of the mangrove crab Ucides cordatus (Crustacea: Decapoda: Brachyura) in the estuary of the Mamanguape river, Northeast Brazil. Tropical Oceanography, v. 32, n. 1, p. 23-37, 2004. https://doi.org/10.5914/tropocean.v32i1.5031

ALVES, R. R. N.; NISHIDA, A. K.; HERNANDEZ, M. I. M. Environmental perception of gatherers of the crab 'caranguejo-uçá' (Ucides cordatus, Decapoda, Brachyura) affecting 
36 LOCAL ECOLOGICAL KNOWLEDGE (LEK) ON THE MANGROVE CRAB Ucides cordatus (LINNAEUS, 1763): FISHERY PROFILE OF MANGROVE AREAS IN ITANHAÉM (SOUTHEAST BRAZIL)

their collection attitudes. Journal of Ethnobiology and Ethnomedicine, v. 1, n. 10, p. 1-8, 2005. https://doi.org/10.1186/1746-4269-1-10

ALVES, B. S.; QUIÑONES, E. M. Análise da degradação da mata ciliar nos afluentes do Rio Itanhaém-SP. Revista Ceciliana, v. 5, n. 2, p. 5-11, 2013.

AMARAL, P. G. C.; LEDRU, M-P.; BRANCO, F. R.; GIANNINI, P. C. F. Late Holocene development of a mangrove ecosystem in southeastern Brazil (Itanhaém, state of São Paulo). Palaeogeography, Palaeoclimatology, Palaeoecology, v. 241, p. 608-620, 2006. https://doi.org/10.1016/j.palaeo.2006.04.010

ANUCHIRACHEEVA, S.; DEMAINE H.; SHIVAKOTI, G. P.; RUDDLE, K. Systematizing local knowledge using GIS: fisheries management in Bang Saphan Bay, Thailand. Ocean \& $\begin{array}{llllll}\text { Coastal Management, } & \text { v. 46, } & \text { p. }\end{array}$ https://doi.org/10.1016/j.ocecoaman.2004.01.001

ANVISA - Agência Nacional de Vigilância Sanitária. Instrução Normativa n. 60, de 23 de dezembro de 2019. Padrões microbiológicos para alimentos. Diário Oficial da União, n. 249, seção 1, p. 133-139, Dec. 26, 2019.

BARBOZA, R. S. L.; NEUMANN-LEITÃO, S.; BARBOZA, M. S. L.; BATISTA-LEITE, L. M. A. "Fui no mangue catar lixo, pegar caranguejo, conversar com o urubu": Estudo socioeconômico dos catadores de caranguejo no litoral norte de Pernambuco. Revista Brasileira de Engenharia de Pesca, v. 3, n. 2, p. 117-134, 2008.

BERNARD, H. R. Research methods in anthropology: qualitative and quantitative approaches. Lanham: AltaMira Press, 2005. 821 p.

BONI, V.; QUARESMA, S. J. Aprendendo a entrevistar: como fazer entrevistas em Ciências Sociais. Revista Em Tese, v. 2, n. 3, p. 68-80, 2005.

BOTELHO, E. R. O.; DIAS, A. F.; IVO, C. T. C. Estudo sobre a biologia do caranguejo-uçá, Ucides cordatus, (Linnaeus, 1763), capturado nos estuários dos rios Formoso (Rio Formoso) e Ilhetas (Tamandaré), no estado de Pernambuco. Boletim Técnico-Científico do CEPENE, v. 7, n. 1, p. 117-145, 1999.

CHRISTOFOlETTI, R. A.; HATTORI, G. Y.; PINHEIRO, M. A. A. Food selection by a mangrove crab: temporal changes in fasted animals. Hydrobiologia, v. 702, p. 63-72, 2013.

CORTÊS, L. H. O.; ZAPPES, C. A.; DI BENEDITTO, A. P. M. Ethnoecology, gathering techniques and traditional management of the crab Ucides cordatus Linnaeus, 1763 in a mangrove forest in southeastern Brazil. Ocean \& Coastal Management, v. 93, p. 129-138, 2014. https://doi.org/10.1016/j.ocecoaman.2014.03.021

CostA, R. S. D. Bioecologia do caranguejo-uçá, Ucides cordatus (Linnaeus, 1763) Crustáceo, Decápode - no Nordeste Brasileiro. Boletim da Sociedade Cearense de Agronomia, v. 20, p. 1-74, 1979.

COSTA-NETO, E. M.; GORDIANO LIMA, K. L. Contribuição ao estudo da interação entre pescadores e caranguejos (Crustacea, Decapoda, Brachyura): considerações etnobiológicas em uma comunidade pesqueira no estado da Bahia, Brasil. Actualidades Biológicas, v. 22, n. 73, p. 195-202, 2000. 
37 LOCAL ECOLOGICAL KNOWLEDGE (LEK) ON THE MANGROVE CRAB Ucides cordatus (LINNAEUS, 1763): FISHERY PROFILE OF MANGROVE AREAS IN ITANHAÉM (SOUTHEAST BRAZIL)

COSTA-NETO, E. M.; ANDRADE, C. T. S.; COUTO, D. F.; MAGALHÃES, H. F.; MASCARENHAS, L. S.; CAMPOS, E. V. M. Diagnóstico etnoecológico em comunidades pesqueiras do município de Conde, região Litoral Norte do Estado da Bahia. In: COSTANETO, E. M.; SANTOS, F. M.; LONDERO, J. C. (Eds.). Novos olhares para o desenvolvimento regional sustentável: caminhos e perspectivas. Santa Cruz do Sul: EDUNISC, p. 20-52, 2010.

DICTORO, V. P.; GALVÃO, D. F; HANAI, F. Y. O estudo das representações sociais e da percepção ambiental como instrumento de análise das relações humanas com a água. Ambiente \& Educação, v. 21, n. 1, p. 232-251, 2016.

DIELE, $\mathrm{k}$. Life history and population structure of exploited mangrove crab Ucides cordatus (L.) (Decapoda: Brachyura) in the Caeté estuary, North Brazil. Bremen: ZMT Contributions 9, 2000. 130 p.

DIELE, K; KOCH, V.; SAINT-PAUL, U. Population structure, catch composition and CPUE of the artisanally harvested mangrove crab Ucides cordatus (Ocypodidae) in the Caeté estuary, North Brazil: Indications for overfishing? Aquatic Living Resources, v. 18, p. 169-178, 2005.

DUARTE, R. Entrevistas em pesquisas qualitativas. Educar, v. 24, p. 213-225, 2004.

DUARTE, L. F. A.; SOUZA, C. A.; NOBRE, C. R.; PEREIRA, C. D. S.; PINHEIRO, M. A. A. Multilevel biological responses in Ucides cordatus (Linnaeus, 1763) (Brachyura, Ucididae), as indicators of conservation status in mangrove areas from the Western Atlantic. Ecotoxicology and Environmental Safety, V. 133, p. 176-187, 2016. https://doi.org/10.1016/j.ecoenv.2016.07.018

DSCSOFT 2.0. Tolteca Informática Available from: http://www.tolteca.com.br/dscsoft20.aspx. Accessed on: Sept. 28, 2018.

FAO - Food and Agriculture Organization of the United Nations. The State of World Fisheries and Aquaculture 2020. Sustainability in action. Rome. 2020. https://doi.org/10.4060/ca9229en

FISCARELLI, A. G.; PINHEIRO, M. A. A. Perfil sócio-econômico e conhecimento etnobiológico do catador de caranguejo-uçá, Ucides cordatus (Linnaeus, 1763), nos manguezais de Iguape ( $\left.24^{\circ} 41^{\prime} \mathrm{S}\right)$, SP, Brasil. Actualidades Biológicas, v. 24, n. 77, p. 39-52, 2002.

FREITAS, A. C.; FURTADO-JÚNIOR, I.; TAVARES, M. C. S.; BORCEM, E. R. Análise socioeconômica e esforço de pesca na captura do caranguejo-uçá - Ucides cordatus (Crustacea: Ucididae) - na Reserva Extrativista Maracanã - costa amazônica do Brasil. Boletim do Museu Paraense Emílio Goeldi Ciências Humanas, v. 10, n. 3, p. 711-722, 2015. https://doi.org/10.1590/1981-81222015000300012

FORATTINI, O. P.; RABELLO, E. X.; PATTOLI, D. Culicoides da região neotropical (Diptera, Ceratopogonidae). II - Observações sobre biologia em condições naturais. Arquivos da Faculdade de Saúde Pública da Universidade de São Paulo, v. 12, n. 1, p. 1-53, 1958. https://doi.org/10.11606/issn.2358-792X.v12i1p1-52

GERHARDINGER, L. C.; HOSTIM-SILVA, M.; MEDEIROS, R. P.; MATAREZI, J.; BERTONCINI, A. A.; FREITAS, M. O.; FERREIRA, B. P. Fishers resource mapping and goliath grouper 
38 LOCAL ECOLOGICAL KNOWLEDGE (LEK) ON THE MANGROVE CRAB Ucides cordatus (LINNAEUS, 1763): FISHERY PROFILE OF MANGROVE AREAS IN ITANHAÉM (SOUTHEAST BRAZIL)

Epinephelus itajara (Serranidae) conservation in Brazil. Neotropical Ichthyology, v. 7, p. 93-102, 2009. https://doi.org/10.1590/S1679-62252009000100012

GLASER, M.; DIELE, K. Asymmetric outcomes: assessing central aspects of the biological, economic and social sustainability of a mangrove crab fishery, Ucides cordatus (Ocypodidae), in North Brazil. Ecological Economics, v. 49, p. 361-373, 2004. https://doi.org/10.1016/j.ecolecon.2004.01.017

HARKOT, P. F. G.; PINHEIRO, M. A. A.; MACHADO, I. C.; BARROS, M. R.; GRAÇA-LOPES, R. da; ÁVILA-DA-SILVA, A. O.; FAGUNDES, L.; TRASMONTE, P.; ZILBERMANN, B. 0 caranguejo-uçá, Ucides cordatus, como recurso pesqueiro no litoral centro de são paulo: uma iniciativa de gestão. São Paulo: Série Relatórios Técnicos, n. 55, 2017.

HATTORI, G. Y.; PINHEIRO, M. A. A. Fertilidade do caranguejo de mangue Ucides cordatus (Linnaeus) (Crustacea, Brachyura, Ocypodidae), em Iguape (São Paulo, Brasil). Revista Brasileira de Zoologia, v. 20, n. 2, p. 309-313, 2003. https://doi.org/10.1590/S010181752003000200022

HUDELSON, P. M. Qualitative research for health programmes. Geneva: World Health Organization, 1994. $102 \mathrm{p}$.

IBAMA - Instituto Brasileiro de Meio Ambiente e dos Recursos Naturais Renováveis. Lagosta, Caranguejo-Uçá e Camarão-do-Nordeste. Brasília: Coleção Meio Ambiente, Série Estudos-Pesca. v. 10, 1994. 190 p.

IBAMA - Instituto Brasileiro do Meio Ambiente e dos Recursos Renováveis. Portaria n. 52, de 30 de setembro 2003. Defeso pesqueiro do caranguejo-uçá (Ucides cordatus) nas regiões sudeste e sul do Brasil. Diário Oficial da União: n. 191, seção 1, p. 123, Oct. 02, 2003.

IBGE - Instituto Brasileiro de Geografia e Estatística. Panorama Itanhaém. 2017. Available from: https://cidades.ibge.gov.br/brasil/sp/itanhaem/panorama. Accessed on: Mar. 15, 2019.

IHAKA, R.; GENTLEMAN, R. R: a language for data analysis and graphics. Journal of Computational and Graphical Statistics, v. 5, p. 299-314, 1996.

JANKOWSKY, M., PIRES, J. S. R.; NORDI, N. Contribuições ao manejo participativo do caranguejo-uçá Ucides cordatus (Linnaeus, 1763), em Cananéia-SP. Boletim do Instituto de Pesca, v. 32, n. 2, p. 221-228, 2006.

$\mathrm{KOCH}, \mathrm{V}$;; WOLFF, M. Energy budget and ecological role of mangrove epibenthos in the Caeté estuary, North Brazil. Marine Ecology Progress Series, v. 228, p. 119-130, 2002.

LEFÉVRE, F.; LEFÉVRE, A. M. C.; TEIXEIRA, J. J. V. O discurso do sujeito coletivo. Uma nova abordagem metodológica em pesquisa qualitativa. Caxias do Sul: EDUCS, 2000. 138 p.

LEFÉVRE, F.; LEFÉVRE, A. M. C. O sujeito coletivo que fala. Interface - Comunicação, Saúde, Educação, v. 10, n. 20, p. 517-524, 2006. https://doi.org/10.1590/S1414$\underline{32832006000200017}$

LEGAT, J. F. A.; LEGAT, A. P.; PEREIRA, A. L. M.; de GÓES, J. M.; GÓES, L. C. F. Caranguejouçá: métodos para captura, estocagem e transporte. Teresina: Embrapa Meio-Norte, 2006. $25 \mathrm{p}$. 
39 LOCAL ECOLOGICAL KNOWLEDGE (LEK) ON THE MANGROVE CRAB Ucides cordatus (LINNAEUS, 1763): FISHERY PROFILE OF MANGROVE AREAS IN ITANHAÉM (SOUTHEAST BRAZIL)

LUTZ, A. Contribuição para o estudo das "Ceratopogoninas" hematofagas encontradas no Brazil. Memórias do Instituto Oswaldo Cruz, v. 4, p. 1-32, 1912. https://doi.org/10.1590/S0074-02761912000100001

MACHADO, I. C.; PICCOLO, N.; BARROS, M. R.; MATSUNAGA, A. M. F.; PINHEIRO, M. A. A. The capture of the mangrove crab (Ucides cordatus) in the estuarine system of SantosSão Vicente: Ethnoecology of the fishermen from Vila dos Pescadores, Cubatão (SP), Brazil. Boletim do Instituto de Pesca, v. 44, n. 2, p. e257, 2018. https://doi.org/10.20950/1678-2305.2018.257

MAGAlHÃES, H. F. de; COSTA-NETO, E. M.; SCHIAVETTI, A. Saberes pesqueiros relacionados à coleta de siris e caranguejos (Decapoda: Brachyura), no município de Conde, Estado da Bahia. Biota Neotropica, v. 11, n. 2, p. 45-54, 2011.

MELO, G. A. S. Manual de identificação dos Brachyura (caranguejos e siris) do litoral brasileiro. São Paulo: Plêiade, 1996. 604 p.

MINAYO, M. C. S. O desafio do conhecimento. Pesquisa qualitativa em saúde. São Paulo: Hucitec, 2006. 406 p.

MPA/MMA - Ministério da Pesca e Aquicultura / Ministério do Meio Ambiente. Instrução Normativa Interministerial MPA/MMA n. 13, de 25 de outubro de 2011. Normas gerais à pesca para Bacia Hidrográfica do Rio Tocantins e período de defeso para as bacias hidrográficas dos rios Tocantins e Gurupi. Brasil: Diário Oficial da União: n. 206, seção 1, p. 127-129, Oct. 26, 2011.

MPA - Ministério da Pesca e Aquicultura. Instrução Normativa n. 9, de 02 de julho de 2013. Normas e padrões para o transporte de caranguejo-uçá, Ucides cordatus, nos estados do Pará, Maranhão, Piauí e Ceará. Diário Oficial da União: n. 126, seção 1, p. 33, 03. Jul. 2013.

NAMORA, R. C., MOTTA, F. S; GADIG, O. B. F. Caracterização da pesca artesanal na praia dos pescadores, município de Itanhaém, costa Centro-Sul do Estado de São Paulo. Arquivos de Ciências do Mar, v. 42, n. 2, p. 60-67, 2009.

NASCIMENTO, S. A. Biologia do caranguejo-uçá Ucides cordatus. Aracaju: Adema, 1993. $48 \mathrm{p}$.

NAScimento. D. M.; AlVES, A. G. C.; AlVES, R. R. N.; BARBOZA, R. R. D.; DIELE, K.; MOURÃO, J. S. An examination of the techniques used to capture mangrove crabs, Ucides cordatus, in the Mamanguape River estuary, northeastern Brazil, with implications for management. Ocean \& Coastal Management, v. 130, p. 50-57, 2016. https://doi.org/10.1016/j.ocecoaman.2016.05.010

NORDI, N. A captura do caranguejo-uçá (Ucides cordatus) durante o evento reprodutivo da espécie: o ponto de vista dos caranguejeiros. Revista Nordestina de Biologia, v. 9, n. 1, p. 41-47, 1994.

NORDI, N.; NISHIDA, K. A.; ALVES, R. R. N. Effectiveness of two gathering techniques for Ucides cordatus in northeast Brazil: Implications for the sustainability of mangrove ecosystems. Human Ecology, v. 37, p. 121-127, 2009. https://doi.org/10.1007/s10745-009$\underline{9214-9}$

NORDHAUS, I.; DIELE, K.; WOLFF, M. Activity patterns, feeding and burrowing behaviour of the crab Ucides cordatus (Ucididae) in a high intertidal mangrove forest in North 
40 LOCAL ECOLOGICAL KNOWLEDGE (LEK) ON THE MANGROVE CRAB Ucides cordatus (LINNAEUS, 1763): FISHERY PROFILE OF MANGROVE AREAS IN ITANHAÉM (SOUTHEAST BRAZIL)

Brazil. Journal of Experimental Marine Biology and Ecology, v. 374, p. 104-112, 2009. https://doi.org/10.1016/j.jembe.2009.04.002

PAIVA-SOBRINHO, R.; ALVES, E. J. Avaliação preliminar do impacto da coleta do caranguejo-uçá (Ucides cordatus), na densidade da espécie em alguns manguezais dos municípios de Ilha Comprida e Cananéia, SP. In: SEMANA NACIONAL DE OCEANOGRAFIA, 13., 2000, Itajaí. Anais... Itajaí: Univale, 2000. p. 486-488.

PINHEIRO, M. A. A.; FISCARELLI, A. G. Manual de apoio à fiscalização do caranguejouçá (Ucides cordatus). Itajaí: UNESP/CEPSUL-IBAMA, 2001. 43 p.

PINHEIRO, M. A. A.; RODRIGUES, A. M. T. Crustáceos sobre-explotados e o Plano Nacional de Gestão dos caranguejos uçá (Ucides cordatus), guaiamú (Cardisoma guanhumı) e do siri-azul (Callinectes sapidus): uma estratégia para evitar que passe ao "status" de ameaçados de extinção. Revista CEPSUL - Biodiversidade e Conservação Marinha, v. 2, n. 1, p. 50-57, 2011.

PINHEIRO, M. A. A.; ALMEIDA, R. Monitoramento da densidade e da estrutura populacional do caranguejo-uçá, Ucides cordatus (Linnaeus, 1763) (Brachyura: Ucididae). In: TURRA, A., DENADAI, M. R (Orgs.). Protocolos para o Monitoramento de Habitats Bentônicos Costeiros. São Paulo: ReBentos, p. 122-133, 2015. ISBN (e-book): 97885-98729-25-1.

PINHEIRO, M. A. A.; SOUZA, C. A.; BORBA, H. Meat yield of the mangrove crab, Ucides cordatus (Linnaeus, 1763) (Crustacea, Brachyura, Ucididae). Boletim do Instituto Pesca, v. 41, n. 1, p. 43-56, 2015.

PINHEIRO, M. A. A.; SANTOS, L. C. M.; SOUZA, C. A.; JOÃO, M. C. A.; DIAS-NETO, J.; IVO, C. T. C. Avaliação do Caranguejo-uçá, Ucides cordatus (Linnaeus, 1763) (Decapoda: Ucididae). In: PINHEIRO, M., BOOS, H. (orgs.). Livro Vermelho dos Crustáceos do Brasil: Avaliação 2010-2014. Porto Alegre, RS: Sociedade Brasileira de Carcinologia - SBC, p. 441-458, 2016.

PINHEIRO, M. F.; ALVES, L. M. C.; SILVA, F. D. S.; CUNHA, M. C. S.; MENDES, E. O.; COSTA, F. N. Características microbiológicas da carne de caranguejo-uçá (Ucides cordatus) comercializada na cidade de São Luís - MA. Boletim do Instituto de Pesca, v. 43, n. 1, p. 44-51, 2017. https://doi.org/10.20950/1678-2305.2017v43n1p44

PINTO, A. B.; PAGNOCCA, F. C.; PINHEIRO, M. A. A.; FONTES, R. F. C.; DE OLIVEIRA, A. J. F. C. Heavy metals and TPH effects on microbial abundance and diversity in two estuarine areas of the southern-central coast of São Paulo State, Brazil. Marine Pollution Bulletin, v. 96, p. 410-417, 2015. https://doi.org/10.1016/j.marpolbul.2015.04.014

MMA - Ministério do Meio Ambiente. Portaria n. 444, de 17 de dezembro de 2014. Lista Nacional Oficial de Espécies da Fauna Ameaçadas de Extinção. Diário Oficial da União: n. 245, seção 1, p. 121-126, Oct. 18, 2014.

PMAP-SP - Programa de Monitoramento da Atividade Pesqueira Marinha e Estuarina do Estado de São Paulo A pesca em Itanhaém. 2018. Available from: http://www.propesq.pesca.sp.gov.br/27/conteudo. Accessed on: Mar. 05, 2021.

RIZZO, M. R. A recomposição das matas ciliares - Um bom exemplo que vem de Pedro Gomes (MS). Revista Eletrônica da Associação dos Geógrafos Brasileiros, v. 1, n. 6, p. 103-125, 2007. 
41 LOCAL ECOLOGICAL KNOWLEDGE (LEK) ON THE MANGROVE CRAB Ucides cordatus (LINNAEUS, 1763): FISHERY PROFILE OF MANGROVE AREAS IN ITANHAÉM (SOUTHEAST BRAZIL)

RODRIGUES, A. M. T.; BRANCO, E. J.; SACCARDO, S. A.; BLANKENSTEYN, A. A explotação do caranguejo Ucides cordatus (Decapoda: Ocypodidae) e o processo de Gestão Participativa para normatização da atividade na Região Sudeste-Sul do Brasil. Boletim do Instituto de Pesca, v. 26, n. 1, p. 63-78, 2000.

SANTOS, A. L. G.; FURLAN, S. A. Manguezais da Baixada Santista, São Paulo - Brasil: uma bibliografia. In: SEMINÁRIO LATINO AMERICANO DE GEOGRAFIA FÍSICA, 6.; SEMINÁRIO IBERO AMERICANO DE GEOGRAFIA FÍSICA, 2., 2010, Coimbra. Anais. Coimbra: Universidade de Coimbra, 2010. 14p.

SANTOS, C. M. H.; PINHEIRO, M. A. A. ; HATTORI, G. Y. (2009). Orientation and external morphology of burrows of the mangrove crab Ucides cordatus (Crustacea, Brachyura, Ucididae). Journal of the Marine Biological Association of the United Kingdom ${ }_{L}$ v. 89, n. 6, p. 1117-1123, 2009. https://doi.org/doi:10.1017/S0025315409000502

SÃO PAULO (Estado) - Governo do Estado de São Paulo. Decreto n. 60.133, de 07 de fevereiro de 2014. Lista de espécies da fauna silvestre ameaçadas de extinção, as quase ameaçadas e as deficientes de dados para avaliação no Estado de São Paulo. Diário Oficial do Estado: n. 124 (27), seção 1 - Poder Executivo, p. 25-32, Feb. 08, 2014.

SCHAEFFER-NOVELLI, Y.; SORIANO-SIERRA, E. J.; DO VALE, C. C.; BERNINI, E.; ROVAI, A. S.; PINHEIRO, M. A. A.; SCHMIDT, A. J.; DE ALMEIDA, R.; COELHO JR, C.; MENGHINI, R. P.; MARTINEZ, D. I.; ABUCHAHLA, G. M. O.; CUNHA-LIGNON, M.; CHARLIER-SARUBO, S.; SHIRAZAWA-FREITAS, J.; CINTRÓN-MOLERO, G. Climate changes in mangrove forests and salt marshes. Brazilian Journal of Oceanography, v. 64, n. sp.2, p. 37-52, 2016. https://doi.org/10.1590/S1679-875920160919064sp2

SCHMIDT, A. J., BEMVENUTI, C. E.; DIELE, K. Effects of geophysical cycles on the rhythm of mass mate searching of a harvested mangrove crab. Animal Behavior, v. 84, p. 333340, 2012. https://doi.org/10.1016/j.anbehav.2012.04.023

\section{SELLTIZ, C. Métodos de pesquisa nas relações sociais. São Paulo: EPU, 1974. 687 p.}

SIEGEL, S.; CASTELLAN JR., N. J. Nonparametric statistics for the behavioral sciences. New York: McGraw-Hill, 1988. 400 p.

SHIH, H. T.; LEE, J. H.; HO, P. H.; LIU, H. C.; WANG, C. H.; SUZUKI, H.; TENG, S. J. Species diversity of fiddler crabs, genus Uca Leach, 1814 (Crustacea: Ocypodidae), from Taiwan and adjacent islands, with notes on the Japanese species. Zootaxa, v. 4083, n. 1, p. 57-82, 2016.

SMA-SP - Secretaria de Estado do Meio Ambiente do Estado de São Paulo. Resolução n. 64, de 30 de setembro de 2015. Condições para o uso excepcional da captura do caranguejo-uçá, Ucides cordatus. Diário Oficial do Estado: n. 125 (183), seção 1 - Poder Executivo, p. 62, Oct. 01, 2015.

SOUTO, F. J. B. Uma abordagem etnoecológica da pesca do caranguejo, Ucides cordatus, Linnaeus, 1763 (Decapoda: Brachyura), no manguezal do Distrito de Acupe (Santo Amaro-BA). Biotemas, v. 20, n. 1, p. 69-80, 2007. https://doi.org/10.5007/\%25x

SOUZA, C. A.; DUARTE, L. F. A.; JOÃO, M. C. A.; PINHEIRO, M. A. A. Biodiversidade e conservação dos manguezais: importância bioecológica e econômica. In: PINHEIRO, M. A. A.; TALAMONI, A. C. B. (Orgs.). Educação Ambiental sobre Manguezais. São Vicente: UNESP, Instituto de Biociências, Câmpus do Litoral Paulista, 2018. p. 16-56. 
42 LOCAL ECOLOGICAL KNOWLEDGE (LEK) ON THE MANGROVE CRAB Ucides cordatus (LINNAEUS, 1763): FISHERY PROFILE OF MANGROVE AREAS IN ITANHAÉM (SOUTHEAST BRAZIL)

SOKAL, R. R.; ROHLF, F. J. Biometry: The principles and practice of statistics in biological research. New York: W.H. Freeman, 2003. 887 p.

SOUZA, F. V. B.; PINHEIRO, M. A. A. 2020. Percepções ambientais e socioeconômicas acerca da extração do caranguejo-uçá (Ucides cordatus) no Sistema Estuarino de Itanhaém (SE Brasil): contribuições à conservação e ao manejo. Revista Brasileira de Meio Ambiente, v. 8, n. 4, p. 175-195, 2020. https://doi.org/10.5281/zenodo.4284547

SOUZA-PEREIRA, P. E. S.; CAMARGO, A. F. M. Efeito da salinidade e do esgoto orgânico sobre a comunidade zooplanctônica, com ênfase nos copépodes, do estuário do rio Itanhaém, Estado de São Paulo. Acta Scientiarum Biological Sciences, v. 26, n. 1, p. 9-17, 2004. https://doi.org/10.4025/actascibiolsci.v26i1.1652

THÉ, A. P. G.; NORDI, N. Common property resource system in a fishery of the São Francisco River, Minas Gerais, Brazil. Human Ecology, v. 13, n. 1, p. 1-10, 2006.

VIDAL, W. C. L.; SASSI, R. Influência do Manguezal na região marinha adjacente à laguna de Jacarapé, João Pessoa, Paraíba, Brasil. In: SILVA, M.J.L. (Org.), Iniciados. João Pessoa: Santa Clara, 1998. p. 89-107.

VIEIRA, S. Como escrever uma tese. São Paulo: Atlas, 2008. 152 p.

WUNDERLICH, A. C.; PINHEIRO, M. A. A.; RODRIGUES, A. M. T. Biologia do caranguejouçá, Ucides cordatus (Linnaeus) (Crustacea, Decapoda, Brachyura), na Baía da Babitonga, Santa Catarina, Brasil. Revista Brasileira de Zoologia, v. 25, n. 2, p. 188-198, 2008. https://doi.org/10.1590/S0101-81752008000200005

Recebido em: 18/03/2021 Aprovado em: 17/05/2021 Publicado em: 12/07/2021 